CZASOPISMO INŻYNIERII LA¿OWEJ, ŚRODOWISKA I ARCHITEKTURY JOURNAL OF CIVIL ENGINEERING, ENVIRONMENT AND ARCHITECTURE JCEEA, t. XXXIII, z. 63 (2/I/16), kwiecień-czerwiec 2016, s. 75-86

\author{
Galina KALDA ${ }^{1}$ \\ Małgorzata WILK ${ }^{2}$
}

\title{
ANALIZA ZANIECZYSZCZENIA GLEBY ZAKŁADAMI PRZEMYSŁOWYMI NA PODKARPACIU
}

\begin{abstract}
W artykule prezentowano źródła zanieczyszczenia i zagrożenia gleby w województwie podkarpackim. Czynnikami wpływającymi na stan chemiczny gleb, jest stopień uprzemysłowienia terenu, natężenie ruchu drogowego, gęstość zaludnienia, struktura powierzchniowa miasta, gospodarka odpadowo-ściekowa, mikroklimat oraz rodzaj i gatunek gleb. Zakłady przemysłowe oraz komunikacja emitują najwięcej pyłowych i gazowych zanieczyszczeń powietrza atmosferycznego. Emisja zanieczyszczeń gazowych i pyłowych nie wywołuje bezpośrednio widocznych skutków w zmianach profilów glebowych, ale ich pośrednie oddziaływanie może mieć duży wkład. W województwie podkarpackim występują liczne zakłady przemysłowe, które są potencjalnym zagrożeniem dla środowiska glebowego. Największa ilość zanieczyszczeń dostaje się do gleby wraz ze ściekami, pyłami, gazami oraz ciekłymi i stałymi odpadami, generowanymi przez przemysł. Zanieczyszczenia te zawierają głównie metale ciężkie czy sole. Poważnym źródłem zanieczyszczeń gleb mogą być występujące na Podkarpaciu zakłady dużego oraz zwiększonego ryzyka, w których przerabiane są w instalacjach produkcyjnych ogromne ilości substancji niebezpiecznych. Zagrożeniem jest także magazynowanie substancji toksycznych oraz ich transport. W artykule pokazana zawartość metali ciężkich w glebach Podkarpacia w 2011-2014 latach, zawartość gazów i pyłów emitowanych z zakładów przemysłowych, ilość gruntów zdegradowanych oraz zdewastowanych na Podkarpaciu. Pokazano, że stan gleby w województwie podkarpackim jest na ogół dobry. Jednak występują tu gleby zakwaszone, wymagające nieraz natychmiastowego wapnowania, oraz gleby zanieczyszczone substancjami chemicznymi. Grunty zdewastowane oraz degradowane powstawały głównie w wyniku działalności górnictwa oraz kopalnictwa surowców. W województwie podkarpackim dotyczyło to głównie gruntów z terenów poeksploatacyjnych górnictwa siarkowego.
\end{abstract}

Słowa kluczowe: gleba, zanieczyszczenie, ochrona, zagrożenie, źródła, zakłady przemysłowe

\footnotetext{
${ }^{1}$ Autor do korespondencji/corresponding author: Galina Kalda, Politechnika Rzeszowska, al. Powstańców Warszawy 12, 35-959 Rzeszów, tel. +48 17 8651068, kaldagal@prz.edu.pl

${ }^{2}$ Małgorzata Wilk, Politechnika Rzeszowska
} 


\section{Wprowadzenie}

Gleba jest najcenniejszym odnawialnym bogactwem naturalnym Ziemi, jest podstawą funkcjonowania wszystkich istniejących ekosystemów lądowych, stanowi naturalne środowisko, potrzebne do rozwoju mikroorganizmów i roślin wyższych, warunkuje rozkład i produkcję biomasy, przepływ energii oraz obieg materii w ekosystemie, jest także filtrem w obiegu wód podziemnych. W wyniku działalności człowieka naturalne właściwości gleby często ulegają trudno odwracalnym przemianom. Gleba buforuje, filtruje, ale także akumuluje substancje szkodliwe, stąd ochrona gleb jest priorytetem w działaniach ochrony środowiska.

Czynnikami, wpływającymi na zanieczyszczenie gleb, jest stopień uprzemysłowienia terenu, natężenie ruchu drogowego, gęstość zaludnienia, struktura powierzchniowa danego obszaru, gospodarka odpadowa, ściekowa, mikroklimat oraz rodzaj i gatunek gleb. Zanieczyszczona gleba pogarsza wegetacje roślin użytkowych oraz estetyczne i ekologiczne walory roślin. Zanieczyszczenia gleb mogą mieć różne pochodzenie, głównym ich źródłem jest przemysł oraz chemizacja rolnictwa. Do zanieczyszczenia gleb dochodzi głównie poprzez przedostawanie się do gleby wszelkich chemicznych substancji, pierwiastków promieniotwórczych oraz mikroorganizmów, występujących w glebach w dawkach, przekraczających ich naturalną zawartość. Skutkiem zanieczyszczenia gleby jest przede wszystkim zmienienie cech gleb pod względem fizycznym, chemicznym i biologicznym. Gleby zanieczyszczone oraz zdegradowane, które utraciły częściowo albo całkowicie swoje pierwotne właściwości fizyczne, chemiczne lub funkcje biologiczne, potrzebują podjęcia działań naprawczych, prowadzących do detoksykacji lub oczyszczenia ich. Aby nie dopuścić do kompletnego zniszczenia gleb, należy podejmować działania zapobiegawcze oraz zdegradowane i zdewastowane gleby należy rekultywować.

Ochrona gleby opiera się na zachowaniu jej wartości, a w szczególności poprzez racjonalne gospodarowanie powierzchnią Ziemi, zachowaniu wartości przyrodniczych, zachowaniu możliwości produkcyjnego jej wykorzystania, utrzymanie jakości gleb na poziomie wymaganych standardów, ograniczaniu zmian naturalnej rzeźby terenu oraz zachowaniu wartości kulturowych, uwzględniając zabytki archeologiczne. Do ochrony gleb należy także monitoring zanieczyszczeń gleb. Monitoring zanieczyszczeń gleb ma na celu badanie i ocenę stanu biologicznie czynnej warstwy powierzchni Ziemi, łącznie z czynnikami powodującymi jej degradację. Punktem docelowym monitoringu gleb jest poprawa efektywności działań w zakresie ochrony gleb.

\section{Charakterystyka gleby w województwie podkarpackim}

Według danych, zgromadzonych przez Główny Urząd Statystyczny w Rzeszowie, powierzchnia geodezyjna województwa podkarpackiego wynosi 1784,6 tys. ha, co stanowi 5,7\% powierzchni kraju. Użytki rolne w wojewódz- 
twie podkarpackim zajmują 943,2 tys. ha, co stanowi 52,9\% ogólnej powierzchni województwa. Grunty leśne i zadrzewione oraz zakrzewione pochłaniają 40,7\% powierzchni, tj. 727,2 tys. ha. Grunty zabudowane i zurbanizowane zajmują 79,8 tys. ha $(4,5 \%)$, grunty pod wodami powierzchniowymi $-20,4$ tys. ha $(1,1 \%)$. Tereny przemysłowe i użytki kopalne stanowią niewielki procent powierzchni województwa podkarpackiego, zajmują łącznie około 6 tys. ha, tj. $0,4 \%$. Pozostałe 13,9 tys. ha ( $0,8 \%$ powierzchni województwa) zajmowały użytki ekologiczne, nieużytki oraz tereny różne.

Ogólny stan gleb w województwie podkarpackim jest dobry, ale występują tu także gleby zakwaszone, wymagające nawet natychmiastowego wapnowania, a także gleby zanieczyszczone substancjami chemicznymi. Z przeprowadzonych badań w latach 2010-2014 wynika, że w województwie podkarpackim przeważają gleby kwaśne oraz bardzo kwaśne. W południowej części województwa podkarpackiego występują gleby, które są ubogie w fosfor i potas. W $2013 \mathrm{r}$. przeprowadzono badania odnośnie zawartości metali ciężkich zawartych w glebach. Badania te pokazały, że stopień zanieczyszczenia chemicznego jest niewielki i wahał się w granicach dopuszczalnych norm. W badaniach tych zauważono tylko jeden przypadek podwyższenia zawartości rtęci. Część gleb jest zdegradowana wskutek działalności przemysłowej, występujących erozji, osuwisk czy eksploatacji surowców mineralnych.

\section{3. Źródła zanieczyszczenia i zagrożenia gleby na Podkarpaciu}

Gleba jest takim elementem środowiska, która gromadzi w sobie zanieczyszczenia z wszystkich pozostałych części. Czynnikami wpływającymi na stan chemiczny gleb, jest stopień uprzemysłowienia terenu, natężenie ruchu drogowego, gęstość zaludnienia, struktura powierzchniowa miasta, gospodarka odpadowo-ściekowa, mikroklimat oraz rodzaj i gatunek gleb.

$\mathrm{Na}$ obszarach miejskich gleby ulegają szeregom przekształceń. Spowodowane jest to tym, że na względnie małym rejonie występuje wiele emitorów zanieczyszczeń. Obszary zurbanizowane charakteryzują się często dużą zawartością substancji chemicznych w glebach. Substancjami tymi są metale ciężkie, związki ropopochodne, związki siarki, fluorowce oraz inne zanieczyszczenia organiczne i mineralne [1].

Mechanicznymi zanieczyszczeniami gleby są różne ciała stałe, słabo rozkładalne o wymiarach cząsteczek elementarnych powyżej $1 \mathrm{~mm}$, które są wprowadzane do gleby lub na powierzchnie gleby. Do mechanicznych zanieczyszczeń gleby zaliczamy gruzy budowlane, gruzy z nawierzchni dróg, odpady różnego pochodzenia, w tym odpady budowlane, poeksploatacyjne surowców skalnych, metalowe, ceramiczne, szklane, z tworzyw sztucznych, odpady przemysłowe, komunalne itp. Istotnym źródłem zanieczyszczeń mechanicznych są składowiska odpadów [2]. 
W województwie podkarpackim w $2014 \mathrm{r}$. funkcjonowało 7 składowisk, deponujących odpady przemysłowe. Łącznie w 2014 r. na tych składowiskach zgromadzono około 0,7 tys. $\mathrm{Mg}$ odpadów przemysłowych. Wśród tych 7 składowisk odpadów przemysłowych dwa są zaliczane do składowisk odpadów niebezpiecznych (mieszczą się one w Dębicy i Pustkowie), jedno składowisko, przyjmujące odpady obojętne (miejscowość Jeziórko) oraz cztery składowiska odpadów przemysłowych innych, niż obojętne i niebezpieczne (w Pustkowie, Mielcu oraz dwa w Jaśle) [2].

Chemiczne zanieczyszczenia gleb powstają przede wszystkim w wyniku nieprawidłowej działalności ludzkiej i prowadzą do degradacji gleb. W porównaniu do powietrza czy wód zanieczyszczonych, gleby nie można tak szybko oczyścić. Jej proces samooczyszczania jest niezwykle powolny. Gleby, które są zanieczyszczone chemicznie, przejawiają niekorzystne zmiany aktywności biologicznej, zmiany właściwości fizycznych oraz są bardziej podatne na erozje wodną i wietrzną. Degradację chemiczną gleb powodują procesy, które kierują do zmiany odczynu gleby, tj. zakwaszenia bądź alkalizacji, oraz do akumulacji śladowych pierwiastków w glebie, a w szczególności metali ciężkich [3].

Zakłady przemysłowe oraz komunikacja emitują najwięcej pyłowych i gazowych zanieczyszczeń powietrza atmosferycznego. Emisja zanieczyszczeń gazowych i pyłowych nie wywołuje bezpośrednio widocznych skutków w zmianach profilów glebowych, ale ich pośrednie oddziaływanie może mieć duży wkład [4].

Poważne zaburzenia w glebie mogą spowodować niektóre odpady kopalniane. Siarka i piryt, wydobyte na powierzchnie gleby, bardzo silnie ją zakwaszą kwasem siarkowym w wyniku utlenienia. Znaczne zanieczyszczenie gleb metalami ciężkimi występuje w nakładzie i pobliskich glebach przy wydobyciu rud metali ciężkich. Istotnym źródłem zagrożenia gleby są także składowiska odpadów, pyły unoszące się znad składowisk oraz nie skanalizowane odcieki wysypiskowe $[4,5]$.

\section{Analiza zanieczyszczeń gleby pochodzących od zakładów przemysłowych w województwie podkarpackim}

W województwie podkarpackim występują liczne zakłady przemysłowe, które są potencjalnym zagrożeniem dla środowiska glebowego. Największa ilość zanieczyszczeń dostaje się do gleby wraz ze ściekami, pyłami, gazami oraz ciekłymi i stałymi odpadami, generowanymi przez przemysł. Zanieczyszczenia te zawierają głównie metale ciężkie czy sole. Dużo zakładów przemysłowych, takich jak huty, elektrownie, cementownie czy zakłady chemiczne, emitują do atmosfery szkodliwe pyły i gazy, które opadają na powierzchnie gleby, zanieczyszczając ją. Zanieczyszczoną glebę można także zaobserwować w pobliżu infrastruktury drogowej. 
Źródłami potencjalnych skutków zanieczyszczenia gleb w województwie podkarpackim są:

- przemysł oraz działalność usługowa, w których są używane lub magazynowane toksyczne środki chemiczne, wytwarzane odpady lub substancje biologicznie czynne, istniejącymi źródłami zagrożeń są np. instalacje amoniakalne w zakładzie WSK, „Zelmer”, „Alimie-Gerber”, PPL „Koral”, zbiorniki chloru w MPWiK, ICN-Polfa;

- transport materiałów niebezpiecznych oraz toksycznych na wszystkich trasach kolejowych w województwie podkarpackim oraz na głównych drogach zewnętrznych, a także na ulicach dojazdowych do zakładów przemysłowych wykorzystujących bądź magazynujących te środki;

- awarie ogólno miejskich systemów zasilania sieci cieplnych, energetycznych, gazu oraz wody;

- gwałtowne pożary zakładów przemysłowych;

- powodzie rzeczne oraz inne ekstremalne zjawiska pogodowe;

- katastrofy budowlane;

- awarie elektrowni jądrowych w sąsiadujących państwach (na Słowacji, Ukrainie lub Węgrzech elektrownie jądrowe wybudowane są z zastosowaniem podobnej technologii, dwustopniowego zabezpieczenia, jak elektrownia w Czarnobylu).

W latach 2013-2014 zakres badań odnośnie zawartości metali ciężkich był mocno ograniczony. Analizą zostało objętych 444 prób gleby, badania miały charakter punktowy i nie można ich odnosić do całego województwa podkarpackiego. W 2013 r. na terenie województwa podkarpackiego ocena zawartości metali ciężkich w glebie została wykonana w oparciu o badanie 215 prób gleby, które zostały pobrane na obszarze 14 powiatów, natomiast w 2014 r. pobrano ponad 140 prób gleby. W tabeli 1 przedstawiona średnia zawartość metali ciężkich w latach 2013-2014 w glebach województwa podkarpackiego (na przykładzie kilku powiatów). Zawartość metali ciężkich w glebach Podkarpacia została określona na podstawie badań zleconych za pośrednictwem producentów rolnych oraz innych zleceniodawców.

Porównując otrzymane wyniki badań w 2013 r. do wartości dopuszczalnych według rozporządzenia w sprawie standardów jakości gleby oraz standardów jakości ziemi, odnotowano tylko jeden przypadek przekroczenia dopuszczalnej wartości w przypadku rtęci na obszarze gminy Świlcza w powiecie rzeszowskim. Pozostałe wyniki badań gleby oscylują w granicach zawartości normatywnej. W 2014 r. nie odnotowano żadnego przekroczenia norm odnośnie zawartości metali ciężkich, wyniki badań podobnie jak w roku wcześniejszym wahają się w przedziałach zawartości normatywnej.

Należy podkreślić, że wyników tych nie można odnosić do całego województwa podkarpackiego, ponieważ wyniki nie zostały przeprowadzone w każdym powiecie oraz ilości prób gleby z każdego powiatu była różna. Poziom zawartości metali ciężkich różnicuje się także w zależności od rodzaju gleby. 
Tabela 1. Zawartość średnia metali ciężkich w glebach województwa podkarpackiego w latach 2013-2014, na podstawie [6-8]

Table 1. Average content heavy metals in soils in the Podkarpacie Voivodship in 2013-2014, based on [6-8]

\begin{tabular}{|c|c|c|c|c|c|c|c|}
\hline \multirow{2}{*}{ Powiat } & \multirow{2}{*}{ Rok } & \multicolumn{6}{|c|}{ Zawartość średnia w mg/kg powietrznie suchej masy gleby } \\
\hline & & kadm & ołów & cynk & miedź & chrom & rtęć \\
\hline \multirow{2}{*}{ brzozowski } & 2013 & 0,35 & 31,3 & 109,9 & 26,1 & 55,4 & 0,079 \\
\hline & 2014 & - & - & - & - & - & - \\
\hline \multirow{2}{*}{ jarosławski } & 2013 & 0,3 & 12,8 & 35,5 & 10,3 & 13,2 & 0,031 \\
\hline & 2014 & 0,3 & 8,0 & 19,4 & 4,2 & 8,4 & 0,013 \\
\hline \multirow{2}{*}{$\begin{array}{l}\text { krośnieński }+ \\
\text { m. Krosno }\end{array}$} & 2013 & 0,33 & 24,2 & 73,3 & 15,75 & 31,1 & 0,065 \\
\hline & 2014 & - & - & - & - & - & - \\
\hline \multirow{2}{*}{ leżajski } & 2013 & 0,3 & 9,8 & 33,8 & 6,7 & 11,3 & 0,046 \\
\hline & 2014 & 0,3 & 15,3 & 36,2 & 9,5 & 18,6 & 0,022 \\
\hline \multirow{2}{*}{$\begin{array}{l}\text { przemyski }+ \\
\text { m. Przemyśl }\end{array}$} & 2013 & 0,3 & 18,2 & 49,9 & 13,9 & 23,1 & 0,037 \\
\hline & 2014 & 0,3 & 23,9 & 74,8 & 24,7 & 38,8 & 0,052 \\
\hline \multirow{2}{*}{ przeworski } & 2013 & 0,3 & 12,3 & - & - & - & - \\
\hline & 2014 & 0,3 & 21,7 & 71,7 & 26,3 & 20,0 & 0,034 \\
\hline \multirow{2}{*}{$\begin{array}{l}\text { rzeszowski } \\
\mathrm{m} . \text { Rzeszów }\end{array}$} & 2013 & 0,3 & 19,7 & 55,1 & 13,8 & 17,5 & 0,074 \\
\hline & 2014 & 0,3 & 19,2 & 77,1 & 29,3 & 24,5 & 0,024 \\
\hline \multicolumn{2}{|c|}{$\begin{array}{l}\text { Dopuszczalna zawartość } \\
\text { metali ciężkich w glebie }\end{array}$} & 4,0 & 100 & 300 & 150 & 150 & 2,0 \\
\hline
\end{tabular}

Problemem w województwie podkarpackim jest wysokie zakwaszenie gleb, które powoduje szybsze przenikanie metali ciężkich do gleb.

Zakłady przemysłowe szczególnie uciążliwe w województwie Podkarpackim w latach 2011-2014 najwięcej emitowały cynku, manganu oraz chromu. W analizowanych latach ilość emisji poszczególnych metali ciężkich co roku jest bardzo podobna. Jednak można zauważyć, ze w 2014 r. emitowano większe masy arsenu, niklu i rtęci niż w latach wcześniejszych, natomiast w 2011 r. prawie o połowę mniej było emitowanego do atmosfery cynku, niż w latach późniejszych.

W 2012 r. wyemitowano najwięcej metali ciężkich do atmosfery, łącznie emisja wynosiła 5,04 tys. kg, zaś w $2011 \mathrm{r}$. najmniej tj. 2,9 tys. kg. W województwie podkarpackim głównie emitowany jest do atmosfery cynk, w latach 2011-2014 stanowił on 73,2\% ogólnej ilości emisji metali ciężkich z zakładów przemysłowych szczególnie niebezpiecznych. W śladowych ilościach były emitowane takie metale ciężkie jak: arsen, kadm, kobalt czy rtęć. 


\subsection{Zawartość gazów i pyłów emitowanych z zakładów przemysłowych w województwie podkarpackim}

Zanieczyszczenia wprowadzane w sposób zorganizowany pochodzą z wszelkiego rodzaju urządzeń technologicznych czy grzewczych, natomiast zanieczyszczenia niezorganizowane pochodzą ze składowisk odpadów przemysłowych, $\mathrm{z}$ hałd kopalnianych, $\mathrm{z}$ hal produkcyjnych oraz $\mathrm{w}$ wyniku prac przeładunkowych różnych substancji sypkich i lotnych.

W tabeli 2 przedstawiono ilość zanieczyszczeń pyłowych i gazowych wprowadzanych do atmosfery w województwie podkarpackim. Wielkość emisji zanieczyszczeń pyłowych dotyczy ilości pyłowych zanieczyszczeń dostarczanych przez dany zakład przemysłowy do atmosfery. Emisja zanieczyszczeń pyłowych obejmuje pyły ze spalania paliw, cementowo-wapiennicze i materiałów ogniotrwałych, węglowo-grafitowe, sadze, nawozów sztucznych. Wielkość emisji zanieczyszczeń gazowych obejmuje dwutlenek węgla, dwutlenek siarki, tlenek azotu, tlenek węgla, metan, podtlenek azotu oraz niezorganizowane zanieczyszczenia.

W latach 2011-2014 emisja pyłów i gazów z zakładów szczególnie uciążliwych w województwie podkarpackim średnio wyniosła 3,6 mln Mg. Z analizowanych lat w $2013 \mathrm{r}$. wyemitowano najwięcej zanieczyszczeń pyłowych oraz gazowych tj. 3,77 mln Mg, najmniej wyemitowano w 2011 r. tj. 3,4 mln Mg.

Tabela 2. Emisja pyłów i gazów z zakładów szczególnie uciążliwych w województwie podkarpackim w latach 2011-2014, na podstawie [6-8]

Table 2. Emissions of dust and gases from the plant particularly burdensome in the Podkarpackie Voivodship in 2011-2014, based on [6-8]

\begin{tabular}{|l|c|c|c|c|c|c|c|c|}
\hline \multirow{2}{*}{ Wyszczególnienie } & \multicolumn{2}{|c|}{$\mathbf{2 0 1 1}$} & \multicolumn{2}{c|}{$\mathbf{2 0 1 2}$} & \multicolumn{2}{c|}{$\mathbf{2 0 1 3}$} & \multicolumn{2}{c|}{$\mathbf{2 0 1 4}$} \\
\cline { 2 - 10 } & $\mathbf{M g}$ & $\mathbf{\%}$ & $\mathbf{M g}$ & $\mathbf{\%}$ & $\mathbf{M g}$ & $\mathbf{\%}$ & $\mathbf{M g}$ & $\mathbf{\%}$ \\
\hline $\begin{array}{l}\text { Emisja zanieczyszczeń pyło- } \\
\text { wych z zakładów szczególnie } \\
\text { uciążliwych ogółem }\end{array}$ & $\underline{1952}$ & $\underline{0,06}$ & $\underline{2002}$ & $\underline{0,05}$ & $\underline{1954}$ & $\underline{0,05}$ & $\underline{1698}$ & $\underline{0,05}$ \\
\hline - ze spalania paliw & 1625 & 0,05 & 1625 & 0,04 & 1595 & 0,04 & 1382 & 0,04 \\
\hline $\begin{array}{l}\text { - cementowo-wapiennicze } \\
\text { i materiałów ogniotrwałych }\end{array}$ & 60 & 0,00 & 59 & 0,00 & 40 & 0,00 & 54 & 0,00 \\
\hline - węglowo-grafitowe, sadza & 33 & 0,00 & 35 & 0,00 & 39 & 0,00 & 36 & 0,00 \\
\hline - nawozy sztuczne & 2 & 0,00 & 4 & 0,00 & 6 & 0,00 & 5 & 0,00 \\
\hline - nie zorganizowane & 1 & 0,00 & 1 & 0,00 & 1 & 0,00 & 13 & 0,00 \\
\hline $\begin{array}{l}\text { Emisja zanieczyszczeńy ga- } \\
\text { zowych z zakładów szcze- } \\
\text { gólnie uciążliwych ogółem }\end{array}$ & $\underline{3402183}$ & $\underline{99,94}$ & $\underline{3767845}$ & $\underline{99,95}$ & $\underline{3701683}$ & $\underline{99,95}$ & $\underline{3360437}$ & $\underline{99,95}$ \\
\hline - dwutlenek węgla & 3383688 & 99,40 & 3746718 & 99,39 & 3681186 & 99,39 & 3342357 & 99,41 \\
\hline - dwutlenek siarki & 8780 & 0,26 & 10337 & 0,27 & 9760 & 0,26 & 8339 & 0,25 \\
\hline - tlenek azotu & 5465 & 0,16 & 6260 & 0,17 & 6066 & 0,16 & 5275 & 0,16 \\
\hline - tlenek węgla & 3570 & 0,10 & 3873 & 0,10 & 3982 & 0,11 & 3504 & 0,10 \\
\hline - metan & 29 & 0,00 & 9 & 0,00 & 6 & 0,00 & 0 & 0,00 \\
\hline - podtlenek azotu & 1 & 0,00 & 1 & 0,00 & 1 & 0,00 & 1 & 0,00 \\
\hline - nie zorganizowane & 7514 & 0,22 & 7742 & 0,21 & 8801 & 0,24 & 9452 & 0,28 \\
\hline Razem & $\mathbf{3 4 0 4 1 3 5}$ & $\mathbf{1 0 0}$ & $\mathbf{3 7 6 9 8 4 7}$ & $\mathbf{1 0 0}$ & $\mathbf{3 7 0 3 6 3 7}$ & $\mathbf{1 0 0}$ & $\mathbf{3 3 6 2 1 3 5}$ & $\mathbf{1 0 0}$ \\
\hline
\end{tabular}


Województwo podkarpackie należy do grupy województw o najniższym wskaźniku emisji zanieczyszczeń pyłowych oraz gazowych do atmosfery. W 2014 r. województwo podkarpackie zajmowało 13 miejsce w kraju odnośnie emisji zanieczyszczeń pyłowych i gazowych.

W 2014 r. tylko 1,6\% emitowanych do atmosfery zanieczyszczeń w Polsce pochodziło z obszaru województwa podkarpackiego. W Polsce głównymi emitorami zanieczyszczeń pyłowych i gazowych są województwa śląskie oraz łódzkie, łącznie te województwa emitują rocznie $38 \%$ zanieczyszczeń pyłowych oraz gazowych w skali kraju. Wynika to $\mathrm{z}$ faktu, że w województwie śląskim oraz łódzkim występują liczne zakłady przemysłowe, huty metali oraz przemysł górniczy.

\subsection{Gleby zdegradowane i zdewastowane w województwie podkarpackim}

$\mathrm{Na}$ terenie województwa podkarpackiego występują gleby zdegradowane oraz zdewastowane $\mathrm{w}$ wyniku działalności przemysłowej oraz rolniczej. Ilość obszarów zdegradowanych oraz zdewastowanych w wyniku działalności przemysłowej w latach 2011-2014 w województwie podkarpackim przedstawiono w tabeli 3 .

Według danych, zgromadzonych przez GUS, w latach 2011-2014 w województwie podkarpackim znajdowało się średnio 1,75 tys. ha gruntów zdegradowanych oraz zdewastowanych. W 2012 r. powstało najwięcej zdegradowanych oraz zdewastowanych terenów tj. 1809 ha. Z analizowanych lat w 2014 r. powstało najmniej zdegradowanych oraz zdewastowanych terenów. Największy udział mają grunty zdewastowane, stanowią one blisko 95\% powierzchni ogólnej gleb wymagających rekultywacji, gleby zdegradowane zajmują pozostałe 5\%.

Największa ilość powierzchni gruntów zdewastowanych oraz zdegradowanych powstała w wyniku natężonej działalności eksploatacyjnej surowców mineralnych, a zwłaszcza kruszyw i siarki (stanowią one około 89\%). Są to przede wszystkim tereny poeksploatacyjne górnictwa siarkowego w obszarze tarnobrzeskim. W rejonie powiatu tarnobrzeskiego znajduje się ponad połowa wszystkich gruntów zdewastowanych oraz zdegradowanych w województwie podkarpackim.

W latach 2011-2014 łącznie zostało zrekultywowanych 673 ha gruntów, zaś zagospodarowanych w tych latach zostało 534 ha gruntów. W latach 2013-2014

Tabela 3. Ilość gruntów zdegradowanych oraz zdewastowanych w województwie podkarpackim w latach 2011-2014, na podstawie [6-8]

Table 3. Amount of land degraded and claims in the Podkarpackie Voivodship in 2011-2014, based on [6-8]

\begin{tabular}{|l|c|c|c|c|}
\hline \multirow{2}{*}{ Wyszczególnienie } & $\mathbf{2 0 1 1}$ & $\mathbf{2 0 1 2}$ & $\mathbf{2 0 1 3}$ & $\mathbf{2 0 1 4}$ \\
\cline { 2 - 5 } & ha & ha & ha & ha \\
\hline Grunty zdegradowane & 62 & 77 & 97 & 123 \\
\hline Grunty zdewastowane & 1653 & 1732 & 1665 & 1574 \\
\hline Ogółem & $\mathbf{1 7 1 5}$ & $\mathbf{1 8 0 9}$ & $\mathbf{1 7 6 2}$ & $\mathbf{1 6 9 7}$ \\
\hline
\end{tabular}


zostało zrekultywowane i zagospodarowane blisko 5 razy więcej obszarów gleb, niż w latach 2011-2012.

Jak przedstawiono $\mathrm{w}$ tabeli 4, w latach 2011-2014 w województwie podkarpackim tylko niewielka część gleb była zrekultywowana oraz zagospodarowana. Analizując tabelę 4, można zauważyć, że z roku na rok rośnie liczba rekultywowanych oraz zagospodarowywanych gleb.

Tabela 4. Ilość gleb zdegradowanych i zdewastowanych w stosunku do ilości gleb poddanych rekultywacji oraz zagospodarowaniu w województwie podkarpackim w latach 2011-2014, na podstawie [6-8]

Table 4. Quantity of degraded soils and claims in relation to the quantities of soil remediation and management in the Podkarpackie Voivodship in 2011-2014, based on [6-8]

\begin{tabular}{|c|c|c|}
\hline \multirow{2}{*}{ Rok } & $\begin{array}{c}\text { Gleby zdewastowane } \\
\text { i zdegradowane }\end{array}$ & $\begin{array}{c}\text { Gleby zrekultywowane i zagospodaro- } \\
\text { wane }\end{array}$ \\
\cline { 2 - 3 } & ha & ha \\
\hline $\mathbf{2 0 1 1}$ & 1715 & 103 \\
\hline $\mathbf{2 0 1 2}$ & 1809 & 105 \\
\hline $\mathbf{2 0 1 3}$ & 1762 & 463 \\
\hline $\mathbf{2 0 1 4}$ & 1697 & 547 \\
\hline
\end{tabular}

W latach 2011-2012 tylko niewielka liczba gleb została zrekultywowana oraz zagospodarowana. W tych latach przywrócono wartość użyteczną tylko około 6\% zniszczonych gleb. W latach 2013-2014 można zauważyć znaczny wzrost zrekultywowanych i zagospodarowanych powierzchni gleb. W $2013 \mathrm{r}$. zrekultywowano oraz zagospodarowano $26,3 \%$ gleb, natomiast w 2014 r. poddano takiemu procesowi $32,2 \%$ gleb.

\section{Zapobieganie zanieczyszczeniom gleby pochodzącymi z przemysłu}

Przeciwdziałanie zanieczyszczeniom środowiska polega na zapobieganiu bądź ograniczaniu wprowadzania do środowiska substancji bądź energii. Podmiot który korzysta ze środowiska jest zobowiązany do przestrzegania wymagań ochrony środowiska, a w szczególności przez [9]:

- odpowiednią organizację prac;

- powierzenie funkcji związanych z zapewnieniem ochrony środowiska osobą dysponującym odpowiednie kwalifikacje zawodowe;

- zapoznanie pracowników, których zakres obowiązków wiąże się z problemem ochrony środowiska, $\mathrm{z}$ wymaganiami w tym zakresie;

- podejmowanie działań w celu uniknięcia lub ograniczenia szkód w środowisku będących rezultatem nieprzestrzegania zasad ochrony środowiska przez pracowników, oraz podejmowania właściwych środków w celu wyeliminowania takich incydentów w przyszłości. 
Aby zminimalizować lub zapobiegać powstawaniu zanieczyszczeniom przemysłowym gleb, powinno się stosować do działań zapobiegawczych, do których można zaliczyć [10]:

- planowanie zagospodarowania przestrzennego obiektów przemysłowych zgodnie z zasadami zrównoważonego rozwoju;

- stosowanie w działalności projektowej, inwestycyjnej, konstrukcyjnej, produkcyjnej oraz techniczno-eksploatacyjnej zakładów przemysłowych, takich rozwiązań, które będą zapewniały bezpieczeństwo ekologiczne;

- projektowanie rozwiązań technicznych, które zminimalizują możliwość wystąpienia nadzwyczajnych zagrożeń środowiska, szczególnie w takich zakładach przemysłowych, w których są produkowane, składowane lub transportowane materiały niebezpieczne;

- stworzenie systemu informowania społeczeństwa o ewentualnych skutkach zanieczyszczenia lub skażenia środowiska glebowego;

- stworzenie zintegrowanych planów do przeciwdziałania nadzwyczajnym zagrożeniom środowiska oraz przygotowanie planu postępowania w wyniku wypadku, awarii czy katastrofy zagrażającej środowisku.

Monitoring środowiska ma obowiązek informować o [11]:

- stanie środowiska oraz jego zmianach;

- źródłach zanieczyszczeń, powodujących degradację środowiska;

- intensyfikacji zanieczyszczeń (obszary na których występuje wysokie stężenie zanieczyszczeń);

- zgodności realizowanych programów środowiskowych;

- skutkach ekologicznych, gospodarczych oraz społecznych degradacji środowiska.

W badaniach laboratoryjnych analiz prób gleb oznacza się: składem granulometryczny gleby, próchnicę, kwasowością hydrolityczną, sumą zasadowych kationów wymiennych, zawartością węgla organicznego, całkowitą zawartością metali ciężkich (miedzi, cynku, ołowiu, kadmu, chromu, niklu, manganu, żelaza), siarki oraz globalną aktywnością beta. W analizie laboratoryjnej oznaczenia materiału roślinnego wykonuje się badania suchej masy, siarki ogólnej, całkowitą zawartość metali i globalną aktywność beta $[12,13]$.

\section{Podsumowanie}

Stan gleby w województwie podkarpackim jest na ogół dobry. Jednak występują tu gleby zakwaszone, wymagające nieraz natychmiastowego wapnowania, oraz gleby zanieczyszczone substancjami chemicznymi. Z przeprowadzonych badań w latach 2011-2014 wynika, że na obszarze województwa podkarpackiego głównie występują gleby kwaśne oraz bardzo kwaśne. Badania prowadzone odnośnie zanieczyszczeń gleb metalami ciężkimi w latach 2011-2014 wykazały, że poziom tych metali oscylował w granicach normy, odnotowano tylko jeden przypadek ( $\mathrm{w} 2013 \mathrm{r}$.) przekroczenia dopuszczalnej wartości 
w przypadku rtęci na obszarze gminy Świlcza (powiat rzeszowski). Należy jednak podkreślić, że wyników tych niemożna odnosić do całego województwa podkarpackiego, ponieważ badania odnośnie metali ciężkich zostały przeprowadzone wybiórczo i nie w każdym powiecie zostały pobrane próby gleb. Powierzchnia gleb wymagających rekultywacji na terenie województwa podkarpackiego w 2014 r. wyniosła 1697 ha, co stanowi 2,6\% ogółu gruntów wymagających rekultywacji w Polsce (dane zgromadzone przez GUS). Grunty zdewastowane (1574 ha) stanowiły zdecydowaną większość w województwie podkarpackim, z czego w 2014 r. zrekultywowane zostały 290 ha (280 ha zrekultywowanych na cele rolnicze oraz 10 ha na cele leśne), a zagospodarowane 247 ha (241 ha na cele rolnicze oraz 6 ha na cele leśne). W latach 2011-2014 powierzchnia gruntów wymagających rekultywacji na obszarze województwa podkarpackiego ulega corocznemu sukcesywnemu zmniejszaniu. Grunty zdewastowane oraz degradowane powstawały głównie w wyniku działalności górnictwa oraz kopalnictwa surowców innych niż energetyczne. W województwie podkarpackim dotyczyło to głównie gruntów z terenów poeksploatacyjnych górnictwa siarkowego. Istotnym problemem wymagającym rozwiązania będzie zakończenie likwidacji kopalni oraz rekultywacji terenów po kopalnictwie siarki i ich zagospodarowanie.

\section{Literatura}

[1] Greinert A., Ochrona i rekultywacja terenów zurbanizowanych, Wydawnictwo Politechniki Zielonogórskiej, Zielona Góra 2000.

[2] Dojlido J., Praca zbiorowa, Ekologia i ochrona środowiska, Wydawnictwo Politechnika Radomska, Radom 1997.

[3] Kowalik P., Ochrona środowiska glebowego, Wydawnictwo Politechniki Gdańskiej, Gdańsk 1999.

[4] Greinert A., Ochrona gleb, Wydawnictwo Politechniki Zielonogórskiej, Zielona Góra 1998.

[5] Nemerow N. L., Aquardy F. J., Sullivan P., Environmental engenineering, John Wiley \& Sons, Inc. 2009.

[6] Raport o stanie środowiska w województwie podkarpackim w 2011 roku. Wojewódzki Inspektorat Ochrony Środowiska w Rzeszowie, Rzeszów 2012.

[7] Raport o stanie środowiska w województwie podkarpackim w 2012 roku. Wojewódzki Inspektorat Ochrony Środowiska w Rzeszowie, Rzeszów 2013.

[8] Raport o stanie środowiska w województwie podkarpackim w 2013 roku. Wojewódzki Inspektorat Ochrony Środowiska w Rzeszowie, Rzeszów 2014.

[9] Ustawa z dnia 27 kwietnia 2001 roku - Prawo ochrony środowiska (Dz. U. z 2001r, nr 62, poz. 627).

[10] Strzałko J., Mossor-Pietraszewska T., Kompendium wiedzy o ekologii, Wydawnictwo Naukowe PWN, Warszawa-Poznań 1999.

[11] Gajdnik B., Wyścicki A., Wybrane aspekty ochrony środowiska i zarządzania środowiskowego, Wydawnictwo Politechniki Śląskiej, Gliwice 2010. 
[12] Państwowa Inspekcja Ochrony Środowiska, Program monitoringu jakości środowiska województwa rzeszowskiego do 1997 roku, Biblioteka Monitoringu Srodowiska, Rzeszów 1995.

[13] Wnuk Z., Wieczorek S., Wybrane zagadnienia z ekologii i ochrony środowiska, Oficyna Wydawnicza Politechniki Rzeszowskiej, Rzeszów 1998.

\title{
RULES FOR SOIL PROTECTION AGAINST POLLUTION FROM INDUSTRIAL PLANTS IN THE PODKARPACIE
}

\begin{abstract}
S u m m a r y
In the article were sources of pollution and soil threats in the Podkarpackie Voivodship. Factors affecting the chemical status of soils is highly urbanized terrain, traffic, population density, structure, the scrap and sewage economy, microclimate and soil type and species. An industrial plants and communication emit the most particulate and gaseous air pollutants. Emissions of gaseous and particulate pollutants do not cause directly visible effect in soil profile changes, but their indirect effects can have a major impact. In the Podkarpackie Voivodship there are numerous industrial plants, which are potential threat to soil environment. A lot of pollutants is getting to the soil along with sewers, dusts, gasses and liquid and permanent waste, generated by the industry. These pollutants contain heavy metals or salts mainly. Plants appearing on Podkarpacie of the great and increased risk, in which in production installations vast quantities are being altered can be the serious source of pollution of the soil of dangerous substances. Also storing toxic substances and their transport are in danger. In the article shows the content of the heavy metals in soils of Podkarpacie in 2011-2014, the gas and dust emitted from industrial plants, amount of land degraded and claims in the Podkarpacie. It has been shown that the state of the soil in the Podkarpackie Viovodship is generally good. However, there are soil acidified, requiring sometimes immediate liming and soil contaminated by chemical substances. Devastated and degraded land mainly as a result of the activities of mining and quarrying raw materials other than energy. In the Podkarpackie Voivodship it mainly land mines stockpiles from the areas of sulfuric acid.
\end{abstract}

Keywords: soil, pollution, protection, threat, source, industrial plants

Przestano do redakcji: $10.02 .2016 r$.

Przyjęto do druku: 1.03.2016 $r$.

DOI: $10.7862 / \mathrm{rb} .2016 .111$ 